\title{
The Obstacles of Using Effective Teaching Methods in Higher Education from the Viewpoint of faculty members of General Science Departments in Kurdistan Region - Iraq
}

\author{
Prof. Dr. Chachan Jumaa Mohammed \\ Duhok University - Kurdistan Region- Iraq \\ Email: chachan.mohammed@uod.ac \\ Heman Ahmad Abdulla \\ Soran University - Kurdistan Region- Iraq \\ Email: hemn.abdulla@gsci.soran.edu.iq
}

\begin{abstract}
This research aims to identify the obstacles to effective teaching in higher education institutions from the viewpoint of faculty members in the departments of general science, and to indicate the significance of the differences in their viewpoints according to demographic variables: (university, gender, degree, academic title, and years of teaching experience). The study sample consisted of (61) faculty members distributed by gender to (33) males and (28) females. The researchers used a questionnaire consisting of (34) items as a tool for data collection. The data was analyzed using the (SPSS) program. The t-test for one-sample, t-test for two independent samples, and ANOVA were applied. The results of the study showed that: "the high cost of purchasing educational equipment" came in the first place among the obstacles, followed by "the students' lack of familiarity with the scientific method of thinking", and then the "reliance of students on memorization without comprehension". The results showed that there were no statistically significant differences between the average scores at the significance level (0.05) according to the demographic variables (university, gender, degree, and years of teaching experience, and academic title). In light of the results, some recommendations were presented.
\end{abstract}

Keywords: effective teaching, faculty members, obstacles, higher education. 


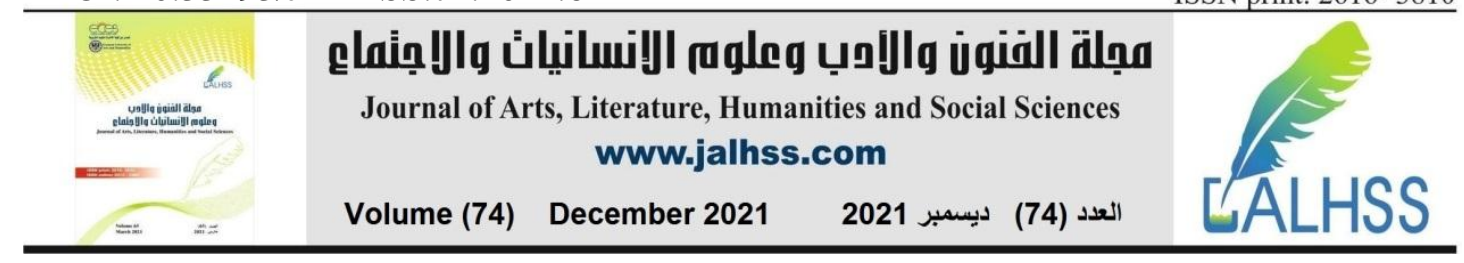

\section{Introduction}

The effective way for promoting student, learning and alertness of context is the use of methods, techniques, and strategy that lead students to grip information about their barricades in the learning process. Anderson (1994) state that: "student outcomes may heavily depend on the teacher's instructional planning, teaching method selection, and having a variety of learning activities." student can be helped by a good teaching strategy when they attempt to students in achieve their life goals and be successful. (Sarode, 2018, p. 58)

The student should be shifted from passive learners to active learners through learning process and implementation of knowledge and skills. In this case young students obtain a better education and prepare to assess a better place in society. Prince (2004), an American author, considers that active learning may be done through any teaching technique that actively engages students in the process of true learning. Obviously, this would help students to understand the subject, rather than memorization. The essence of learning is active participation of learners in the learning process. Zanchin (2002), an Italian author, believes that "active teaching entails students' participation in the delivery of curriculum content. This helps them build procedural knowledge and integrate it with declarative and metacognitive information". (Mocinic, 2012, p. 98)

Each person's definition of a good teacher is different. Students have various perceptions, ideas, and/or experiences of a good instructor. An excellent teacher has been described as a perfectionist, encouraging, approachable, and compassionate at times, and as intelligent at other times, but most importantly as enthusiastic, amusing, witty, affective, and understanding, open, and with a relaxed style at other times. In 1964, Holt stated that the teacher's expertise, excitement, and responsibility for creating a welcoming classroom climate enhance "the pupils desire to learn and accept the difficulties of thinking and enquiring into all that the teacher offers."

Stronge et al. (2004) believes that teaching is a profession, and the most effective instructors are enthusiastic about what they do. He did add, however, that a good teacher is always learning because of changes in the learners' qualities, the curriculum, the community, and finances, among other things(Moreno, 209, p.35036).

The anonymous feedback is a way of reconsideration of learning process in which most of academic institutes use during the learning process. These ratings of teacher effectiveness have been a hot topic since they were first used in the mid1920s (Chang, 2001), That would be a challenge to those organizations in term of good and approach, the student feedback have change over time. Ory (2000) believe that the change form assisting students with course choice to assisting faculty members and assisting administrators with staffs decisions

Teaching is a process that often occurs in a classroom setting. It is more of a formal process in which the instructor makes every effort to ensure that the students understand his teaching. His teaching is only successful if the learners fully comprehend it. The teacher's ability to teach in the classroom is determined by how he or she conducts his or her teaching duties. When there is an explosion of knowledge in this age of science and technology. The learning process has taken on new 


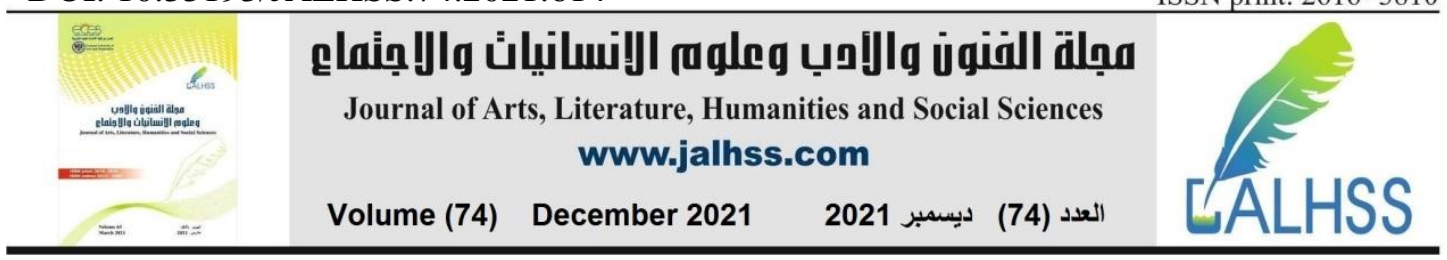

dimensions. A perfect learning process is like a two-way street in which both students and teacher are engaged in the same process. Teaching may consist of both formal and informal setting. In both case the stated goals will be achieved. When time passes by society along its values and ideals develops, and the way students learn will evolve. Teaching will be praised by certain group of people, because it is a distinguished occupation. In higher education professional teachers can be distinguished by certain traits, traits like specific teaching ability, professional teacher teach and learns from their students, the use educational theorist along with their experience to enhance students' knowledge. (Rangaswamy, 2013)

The teaching literature is packed with well-researched methods for teachers to bear knowledge and skills to students that will improve their learning prospects. There isn't a specific skill to have a best teaching methods rather teachers or students can say about a comfortable way to satisfy their feeling of learning and teaching. (Sajjad, 2010)

\section{Research Problem}

The researchers noticed that there is a wide debate in our society between specialists and non-specialists in educational affairs about the decline in the educational level in general at all educational levels, starting from basic education and ending with higher education. The reason for this may be attributed to the ineffective teaching methods that spread in our educational institutions, which adopt traditional methods of teaching and in which the greatest burden is placed on the shoulders of the teacher and the student's role in them is passive and is limited to listening, while we find that modern and effective methods of teaching focus on the active and positive role of the student in the educational process.

As the researchers noticed through their work at the university, some teachers are not good at using some effective teaching skills as required, such as communication skills, the art of dealing with students, the skill of formulating and directing questions, the skill of using modern teaching methods, and they continue to follow the traditional method of explaining lessons, which leads to stagnation quotas and negative recipient.

The current research problem can be framed with the following question:

What are the main obstacles facing effective teaching from the point of view of faculty members at general sciences departments in higher education institutions in the Kurdistan Region of Iraq?

\section{Importance of the Research}

The Current research derives its importance from the following points:

1. The current research may be a new addition to scientific research and studies related to the topic of requirements and obstacles to effective teaching in higher education in Kurdistan.

2. The results of this research may benefit decision-makers in higher education institutions in improving the performance of these institutions and developing 
teaching in them, so that teaching in them is organized, purposeful and effective.

3. This research may benefit those in charge of the educational process in universities and the Ministry of Education with new information that helps them in training faculty members on effective teaching methods.

4. An attempt to find solutions to overcome some of the obstacles that hinder effective teaching in higher education institutions by providing some of the requirements necessary for effective teaching.

\section{Aims of the Research}

1. This research aims to identify the obstacles to effective teaching in higher education institutions from the teachers 'point of view of general sciences departments.

2. Revealing the significance of the differences in the views of staff members about the obstacles facing effective teaching in higher education institutions in the Kurdistan Region according to demographic variables: (university, gender, certificate, academic title, and years of experience in teaching).

\section{Limitations of the study} limits:

The generalization of the results of this research is determined in the following

Objective limits: This research was based on Knowledge of the Constraints to applying effective teaching methods in Higher Education from the Viewpoint of faculty members in the Departments of General Science in Kurdistan Region - Iraq.

Location limits: This research is limited to faculty members in general sciences departments at public universities in the Kurdistan Region - Iraq.

Time Limit: This study was conducted in the academic year 2020/2021.

\section{Theoretical background}

\section{Concept of effective teaching}

Obi (2003) describes effective teaching "as a process related to the teachers actively conscious of the individuality of each of the child, including his needs, strengths, weaknesses, growth patterns and background of experiences. This implies that effective teaching is the process by which an effective teacher creates an atmosphere for a wholesome teaching and learning." (Duvie, 2012, p. 146)

Afaf (2014) Definition of effective teaching: It is that style of teaching that plays the role of the student in learning, in which he is not only a recipient of information, but is also positive, active, participating and searching for information in various possible ways. (Mustafa, 2014, p. 51)

Effective teaching: It is teaching that enables students to acquire skills, knowledge and attitudes that they enjoy. (Ratib Qassem Ashour, 2004, p. 289) 


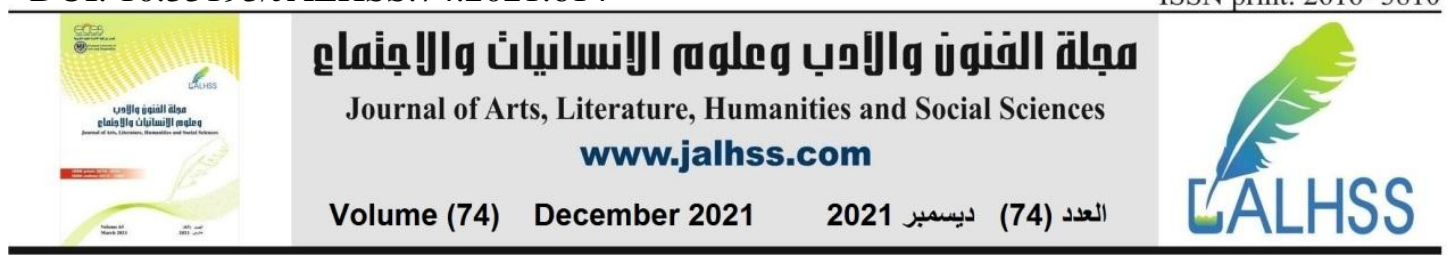

According to McKeachie (1994) Effective teaching as "the degree to which one has facilitated student achievement of educational goals." (Hativa, 2000, p. 38)

Hativa (200) defined effective teaching it here roughly as teaching that brings about effective and successful student learning that is deep and meaningful. Successful teaching entails "the positive changes produced in students in relevant academic domains including the cognitive, affective, and occasionally the psychomotor ones". (Hativa, 2000, p. 11)

Kyriacou (2009) can be defined "effective teaching as that teaching that successfully achieves the learning by pupils intended by the teacher" (Kyriacou, 2009)

Teaching effectiveness is dependent upon the interaction between the teacher's subject-matter knowledge and teaching (pedagogical) ability. The following scenarios illustrate the nature of the complex interaction between these two critical variables:

1. An individual may possess a substantial amount of subject-matter knowledge, yet be unable to design and implement instructional methods to enhance student learning due to a lack of pedagogical ability.

2. Conversely, an individual may possess some generic pedagogical skills, yet have limited subject-matter knowledge and again be predisposed to ineffective teaching. These scenarios indicate that it is impossible to be an effective teacher without being competent in both subject matter knowledge and pedagogical ability. Consequently, subject-matter knowledge remains a necessary prerequisite for effective teaching, not the sole determinant. (Sean M. Bulger, 2000)

A complete understanding of process of learning that is to say; how and why certain activity lead to learning and therefore influence on its effectiveness, is what is so called effective teaching. In order to make sure the learning process happen effectively, teachers should use a whole range of teaching skills. Provide a solid foundation for effective learning needs a combination of both subject matter knowledge and understanding of the nature of effective teaching. (Kyriacou, 2009, p. 1)

Effective teaching takes to accounts how students learn best. For instance, there are differences between students reading learning through listening, or reading or etc. their preferred styles of learning ought to be discovered. And by the way it is known that there are individual differences among students. So it requires that all learning activities should be considered. (JHPIEGO., 2005, pp. 1-7)

Effective teaching involves knowing teacher how to teach the subject matter thoughrolly. There are characteristic that teacher should have like problem- solving, analysing ability, and strategy making. None of these certainly happens in void. (Skelton, 2004, p. 452)

Effective teaching is a social challenging as well teachers what students know, how they communicate then they will be able to know how to teach them. Atkins (1986) also believes that the effective teaching is not depending totally on teachers. There are responsibilities for students as well. And teachers should be explicitly talked about that they can do it indirectly. By improve the ways in which student 


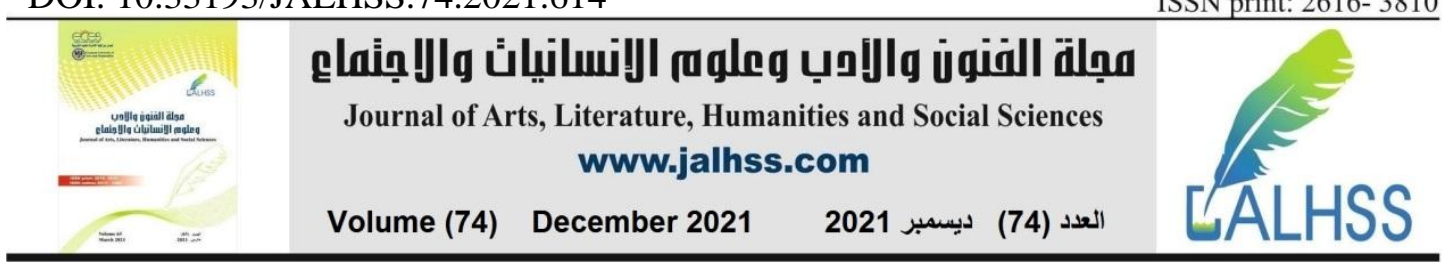

learn. However the teacher role is more collective and rather professional that can be aided by their department. (Atkins, 1988, pp. 1-2)

Another requirement of effective teaching is planning teachers are responsible for planning of their course. A careful time management and preparation for a careful planning is needed. Preparation many include introduction, demonstration, and practice of related concepts such as student assessment to selecting teaching methods, identifying learning materials and developing a course book. (JHPIEGO., 2005, pp. 31)

The idea of effective learning is understood to be directly connected to effective teaching. Effective teaching can be thought of as being the process of making student learning possible. And yet, as student learning is possible on a number of different levels, ranging from deep to superficial, it is more than this alone. Effective teaching is considered in this project, then, to mean teaching that creates an environment in which deep learning outcomes for students are made possible, where high quality student learning is promoted, and where superficial approaches to learning are discouraged. (Ramsden, 1992, p. 86)

\section{The characteristics of effective teaching}

Effective teaching has characteristics that distinguish it, among which (Al-Deeb, 2007, p. 26), (Attia, 2008, p. 63) and (Al-Zahrani, 2010, p. 25) mentioned the following characteristics:

1-It should be suitable for the learner in terms of the time it requires and the effort it makes. The more learning is appropriate to the learner's ability and willingness in terms of his time, and the effort it requires, the easier it will be for him.

2-That the goal be clear and meaningful to the learner, related to his needs and tendencies, and serve the requirements of his life. The more meaningful the learning is to the learner, the more he will gain and desire it, and the easier it will be for him.

3-To make an impression on the learner. Whenever learning has an impact on the learner's soul, he feels with him the change he has brought about in his behavior, the more effective it is, the more it will be rewarded and rewarded.

4-It should be based on the learner's understanding and awareness, so that it is continuous, i.e. applicable, and generalizable and employed in other situations. Effective Teaching is what enables the learner to use it and benefit from it in new situations.

5-To be self-directed based on the learner's initiative and activity, the more individual learning is away from verbal and indoctrination, and the learner appreciates and evaluates the results obtained, the more effective it is.

6-That it be based on strengthening the learner and arousing his motivation with reward instead of punishment, as it was found that reward encourages learning more than punishment, meaning that responding to learning stimuli if accompanied or followed by reward, it strengthens and the learner keeps it. 


\begin{tabular}{|c|c|c|c|c|}
\hline 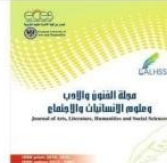 & $\begin{array}{l}\text { Qlninll|g } \\
\text { Journal of As }\end{array}$ & $\begin{array}{l}\text { tsill|l mgln } \\
\text { ts, Literature, Hun } \\
\text { www.jalhs }\end{array}$ & 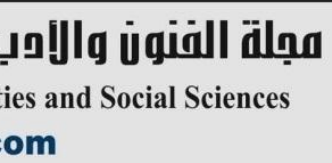 & \\
\hline$=$ & Volume (74) & December 2021 & العدد (74) ديسمبر 2021 & \\
\hline
\end{tabular}

\section{Previous Studies}

(Mwanamoomba, 2014) Aimed to examine the effective methods of teaching at higher level of education, how lecturers figured out methods of teaching as one planned a lesson prior to teaching. The sample of the study included (67), The members consisted of both lecturers (7) and the student teachers (60). The results revealed that little student teachers were aware of learning style(s). But most student teachers were aware of their favorite method, and the selection of the methods dependent on the different factors, it was also found that all methods are important for teaching so teachers should use different methods in one lesson lecturers.

(NAHID SHIRANI BIDABADI, 2016) In a qualitative study aimed to examine the effective teaching in higher education in Iran based on the experiences of best professors in the country and the best local professors of Isfahan University of Technology. The results revealed that the Professors participating prefer the mixed method (student-centered together with teacher-centered), also educational planning and prior readiness, Tutors participating in this study believed that teaching and learning in higher education is a shared process, with responsibilities on both student and teacher to contribute to their success. In this study, it was showed that a good teaching method supports the learners to question their preconceptions, and motivates them to learn, by putting them in a situation in which they come to see themselves as the authors of answers, as the agents of responsibility for change. However teaching through this method has some obstacles and requirements, to have an effective teaching.

(Al-Maqati, 2018) wanted to determine obstacles to the application of modern teaching strategies in the teaching of religious science courses at the secondary stage for courses system from the point of view of teachers. The population of the study consisted of all the teachers of religious science at the courses system secondary schools, they were (153) teachers during second semester of the academic year 2013.and, the sample of the study random included of (53) teachers. The researcher used questionnaire to identify obstacles to the application of modern teaching strategies, which consisted of (32) items, divided into four themes. The results discovered degree level of the obstacles the learning environment is the first, and teacher, then the obstacles the student, and finally the obstacles related to courses. The results revealed no statistically significant differences at the level of significance (0.05) in the obstacles of the application of teaching strategies in the teaching of modern religious science courses depending on the variables: academic qualification, and the experience years.

\section{Research methodology Design of the research:}

This research is a quantitative research, and it uses a descriptive comparative research method, focused on the perceptions of the faculty members at General Science Departments in Kurdistan Region - Iraq about obstacles of effective teaching 


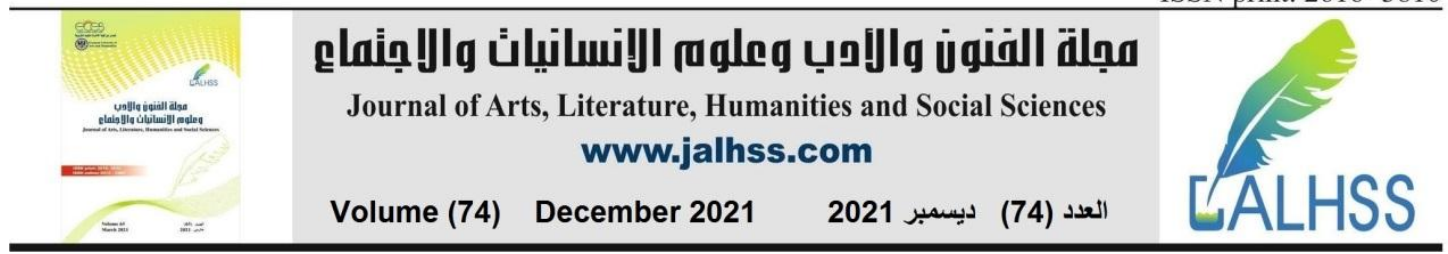

in higher educational institutes. To answer the objectiveness posited in this study, relevant data were gathered using a well design questionnaire which was mailed to a randomly selected sample of General Science teachers in the Kurdistan Region - Iraq.

\section{Population and Sampling of the study}

The population of the current research consists of (107) faculty members in the general sciences departments at the public universities of the Kurdistan RegionIraq. Where the sample of the study consisted of (61) faculty members which divided into (33) males and (28) females .

\section{Research tool}

The researcher applied a structured questionnaire as a tool to collect data of the study the questionnaire consisted of (34) items each one represents an obstacle and divided into five themes or dimensions.

\section{Statistical Analysis:}

Data were analyzed by using the Statistical Package for Social Sciences (SPSS). The statistical procedures used for data analysis in this study included frequencies, t-test for one samples, t-test for two independent samples, and (ANOVA) test.

\section{Result of the study:}

1. Results related to the first objective: Identify the obstacles to effective teaching in higher education institutions from the faculty members 'point of view of general sciences departments.

The result in table (1) shows the mean and ranking of all obstacles for effective teaching from the viewpoint of teaching general sciences departments in higher education institutions in the Kurdistan Region of Iraq.

Table (1)

The one-sample t-test and ranking of each obstacles

\begin{tabular}{|c|l|c|c|c|c|c|c|}
\hline No & \multicolumn{1}{|c|}{ Items } & Mean & Std. & $\mathrm{t}$ & $\mathrm{df}$ & Sig. & Rank \\
\hline 1 & $\begin{array}{l}\text { Disregarding the importance of } \\
\text { body languag in the training } \\
\text { courses. }\end{array}$ & 3.442 & 1.190 & 2.904 & 60 & .005 & 15 \\
\hline 2 & $\begin{array}{l}\text { Lack of accurate knowledge on } \\
\text { scientific subjects in teaching. }\end{array}$ & 3.623 & 1.157 & 4.205 & 60 & .000 & 6 \\
\hline 3 & $\begin{array}{l}\text { Lack of knowledge in training and } \\
\text { pedagogy. }\end{array}$ & 3.655 & 1.236 & 4.141 & 60 & .000 & 4 \\
\hline 4 & $\begin{array}{l}\text { Ambiguity in concepts and meaning } \\
\text { in teaching process. }\end{array}$ & 3.393 & 1.201 & 2.558 & 60 & .013 & 18 \\
\hline 5 & $\begin{array}{l}\text { Distortion in identifying and } \\
\text { defining the teaching subject. }\end{array}$ & 3.426 & 1.117 & 2.979 & 60 & .004 & 16 \\
\hline 6 & $\begin{array}{l}\text { Lack of interest in self-training } \\
\text { towards modern teaching }\end{array}$ & 3.606 & 1.158 & 4.088 & 60 & .000 & 7 \\
\hline
\end{tabular}




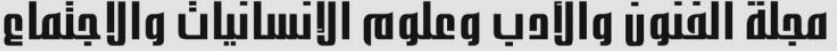

Journal of Arts, Literature, Humanities and Social Sciences www.jalhss.com

Volume (74) December 2021 العدد (74) ل

\begin{tabular}{|c|c|c|c|c|c|c|c|}
\hline & approaches. & & & & & & \\
\hline 7 & Teachers' lack of teaching skills. & 3.541 & 1.311 & 3.223 & 60 & .002 & 10 \\
\hline 8 & Student conflicts in the classroom. & 3.229 & 1.131 & 1.585 & 60 & .118 & 20 \\
\hline 9 & $\begin{array}{l}\text { Lack or unavailability of scientific } \\
\text { teaching equipment and materials. }\end{array}$ & 3.524 & 1.421 & 2.883 & 60 & .005 & 11 \\
\hline 10 & $\begin{array}{l}\text { Negative attitudes of some teachers } \\
\text { towards their profession. }\end{array}$ & 3.393 & 1.228 & 2.501 & 60 & .015 & 18 \\
\hline 11 & $\begin{array}{l}\text { Weakness in teaching ownership of } \\
\text { essential entrepreneurial skills. }\end{array}$ & 3.508 & 1.119 & 3.544 & 60 & .001 & 12 \\
\hline 12 & $\begin{array}{l}\text { Lack of teachers' interest in } \\
\text { professional development. }\end{array}$ & 3.442 & 1.162 & 2.974 & 60 & .004 & 15 \\
\hline 13 & $\begin{array}{l}\text { Student's disengagement in } \\
\text { identifying a goal and pursuing it. }\end{array}$ & 3.426 & 1.230 & 2.704 & 60 & .009 & 16 \\
\hline 14 & $\begin{array}{l}\text { Inadequate self-confidence of } \\
\text { teachers in teaching and dealing } \\
\text { with students. }\end{array}$ & 3.393 & 1.173 & 2.620 & 60 & .011 & 18 \\
\hline 15 & $\begin{array}{l}\text { Lack of self-confidence of teachers } \\
\text { in their scientific subjects. }\end{array}$ & 3.409 & 1.188 & 2.693 & 60 & .009 & 17 \\
\hline 16 & $\begin{array}{l}\text { Teacher's inexperience in utilizing } \\
\text { various teaching methods. }\end{array}$ & 3.704 & 1.229 & 4.478 & 60 & .000 & 2 \\
\hline 17 & $\begin{array}{l}\text { Teacher's limited ability to use } \\
\text { teaching equipment. }\end{array}$ & 3.704 & 1.115 & 4.935 & 60 & .000 & 2 \\
\hline No & Items & Mean & Std. & $\mathrm{t}$ & $\mathrm{df}$ & Sig. & Rank \\
\hline 18 & Lack of classroom management. & 3.442 & 1.147 & 3.012 & 60 & .004 & 15 \\
\hline 19 & $\begin{array}{l}\text { Disregarding the individuality in the } \\
\text { classroom by the teacher. }\end{array}$ & 3.573 & 1.203 & 3.723 & 60 & .000 & 9 \\
\hline 20 & $\begin{array}{l}\text { Lack of feedback provision in the } \\
\text { classroom. }\end{array}$ & 3.393 & 1.158 & 2.652 & 60 & .010 & 18 \\
\hline 21 & Not training students to self-control. & 3.459 & 1.162 & 3.083 & 60 & .003 & 14 \\
\hline 22 & $\begin{array}{l}\text { Students' lack of confidence in } \\
\text { themselves and their surroundings. }\end{array}$ & 3.491 & 1.259 & 3.049 & 60 & .003 & 13 \\
\hline 23 & $\begin{array}{l}\text { Weak or infrequent interaction } \\
\text { between the teachers and learners }\end{array}$ & 3.639 & 1.111 & 4.494 & 60 & .000 & 5 \\
\hline 24 & $\begin{array}{l}\text { Teachers' absence of any } \\
\text { expectation of their students. }\end{array}$ & 3.524 & 1.058 & 3.871 & 60 & .000 & 11 \\
\hline 25 & $\begin{array}{l}\text { Absence of teaching various } \\
\text { knowledge curricula. }\end{array}$ & 3.360 & 1.183 & 2.380 & 60 & .021 & 19 \\
\hline 26 & $\begin{array}{l}\text { Unawareness of the availability of } \\
\text { various learning ways students } \\
\text { learn. }\end{array}$ & 3.655 & 1.167 & 4.387 & 60 & .000 & 4 \\
\hline 27 & $\begin{array}{l}\text { Students are unfamiliar with the } \\
\text { scientific approach in thinking. }\end{array}$ & 3.704 & 1.159 & 4.748 & 60 & .000 & 2 \\
\hline 28 & $\begin{array}{l}\text { Focusing excessively on the } \\
\text { scientific subject rather than the }\end{array}$ & 3.623 & 1.226 & 3.965 & 60 & .000 & 6 \\
\hline
\end{tabular}




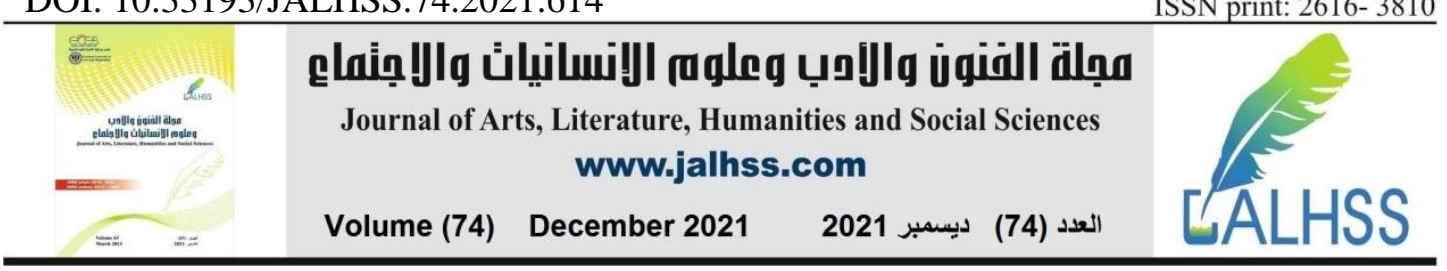

\begin{tabular}{||l|l|c|c|c|c|c|c|}
\hline & students. & & & & & & \\
\hline 29 & $\begin{array}{l}\text { Not paying attention to students' } \\
\text { interests and encouraging them to } \\
\text { work on what they are passionate } \\
\text { about. }\end{array}$ & 3.655 & 1.138 & 4.498 & 60 & .000 & 4 \\
\hline 30 & $\begin{array}{l}\text { Teacher's lack of support to } \\
\text { students to become independent and } \\
\text { rreative. }\end{array}$ & 3.672 & 1.121 & 4.682 & 60 & .000 & 3 \\
\hline 31 & $\begin{array}{l}\text { Students' reliance on memorization } \\
\text { without comprehension. }\end{array}$ & 3.672 & 1.387 & 3.785 & 60 & .000 & 3 \\
\hline 32 & $\begin{array}{l}\text { Ambiguity in teaching style and } \\
\text { identification of the learning } \\
\text { objectives. }\end{array}$ & 3.590 & 1.216 & 3.790 & 60 & .000 & 8 \\
\hline 33 & $\begin{array}{l}\text { High cost of purchasing the learning } \\
\text { equipment. }\end{array}$ & 3.737 & 1.236 & 4.658 & 60 & .000 & 1 \\
\hline 34 & $\begin{array}{l}\text { Technology illiteracy among some } \\
\text { teachers and students. }\end{array}$ & 3.360 & 1.049 & 2.684 & 60 & .009 & 19 \\
\hline
\end{tabular}

These results Indicated that Item number (33) "High cost of purchasing the learning equipment" came in the first ranking between obstacles, with the arithmetic mean (3.737) and standard deviation (1.236). Followed item number (16) "Teacher's inexperience in utilizing various teaching methods" with the arithmetic mean (3.704) and standard deviation (1.229), paragraph number (17) "Teacher's limited ability to use teaching equipment" with the arithmetic mean (3.704) and standard deviation (1.115), and paragraph number (27) "Students are unfamiliar with the scientific approach in thinking" with the arithmetic mean (3.704) and standard deviation (1.159). They are same ranking. Then paragraph number (30) "Teacher's lack of support to students to become independent and creative" with the arithmetic mean (3.672) and standard deviation (1.121), and paragraph number (31) "Students" reliance on memorization without comprehension" with the arithmetic mean (3.672) and standard deviation (1.387), they're same ranking. Also paragraph number (3) "Lack of knowledge in training and pedagogy" with the arithmetic mean (3.655) and standard deviation (1.236), paragraph number (26) "Unawareness of the availability of various learning ways students learn" with the arithmetic mean (3.655) and standard deviation (1.167), and paragraph number (29) "Not paying attention to students' interests and encouraging them to work on what they are passionate about" with the arithmetic mean (3.655) and standard deviation (1.138), have the same ranking which is the fourth ranking. The paragraph number (23) "Weak or infrequent interaction between the teachers and learners" came the fifth ranking with the arithmetic mean (3.639) and standard deviation (1.111). While paragraph number (2) "Lack of accurate knowledge on scientific subjects in teaching" with the arithmetic mean (3.623) and standard deviation (1.157), and paragraph number (28) "Focusing excessively on the scientific subject rather than the students" with the arithmetic mean 


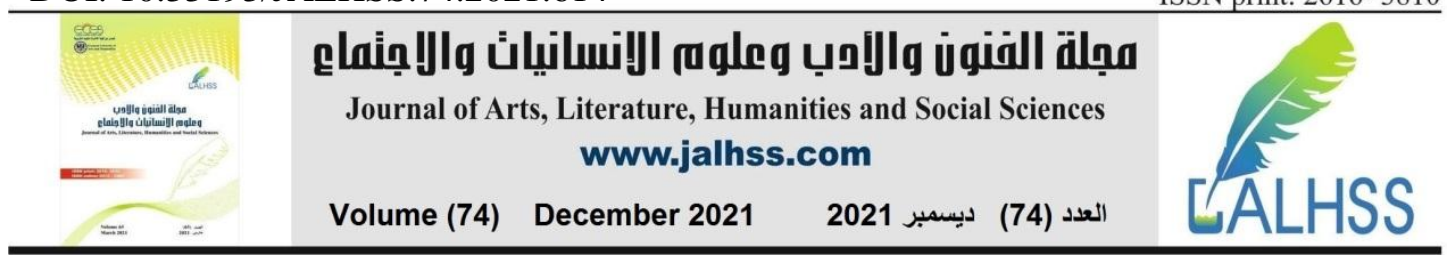

(3.623) and standard deviation (1.226), they are came sixth ranking. Paragraph number (6) "Lack of interest in self-training towards modern teaching approaches" came in the seventh ranking with the arithmetic mean (3.606) and standard deviation (1.158). Followed paragraph number (32) "Ambiguity in teaching style and identification of the learning objectives" with the arithmetic mean (3.590) and standard deviation (1.216) . Then Paragraph number (19) "Disregarding the individuality in the classroom by the teacher" came in the seventh ranking with the arithmetic mean (3.573) and standard deviation (1.203). Paragraph number (7) "Teachers' lack of teaching skills" came in the tenth ranking with the arithmetic mean (3.541) and standard deviation (1.311). The sixteen above paragraphs are calculate as the higher obstacles for effective teaching from the point of view teachers at general science department in Kurdistan Region - Iraq.

2.Results related to the second objective: Revealing the significance of the differences in the views of faculty members about the obstacles facing effective teaching in higher education institutions in the Kurdistan Region according to demographic variables( university, gender, certificate, academic title, and years of experience in teaching).

\section{A. Differences according to university variable:}

The results of the comparison using one-way analysis of variance indicated that there are no statistically significant differences in the total scores of obstacles among faculty members according to the university variable, as the calculated Fvalues was equal to (0.426) and it is not statistically significant at the level of significance $(0.05)$ and degrees of freedom $(4 ; 56)$. As shown in table (2).

Table (2)

The differences in total obstacles according to university

\begin{tabular}{|c|c|c|c|c|c|}
\hline \multicolumn{7}{|c|}{ ANOVA } \\
\hline Source & $\begin{array}{c}\text { Sum of } \\
\text { Squares }\end{array}$ & df & Mean Square & F & Sig. \\
\hline Between Groups & 1903.386 & 4 & 475.847 & .426 & .790 \\
\hline Within Groups & 62617.598 & 56 & 1118.171 & & \\
\hline Total & 64520.984 & 60 & & & \\
\hline
\end{tabular}

\section{$B$.Differences according to gender variable:}

The results of using the t-test for two independent samples showed that there was no statistically significant difference between the mean of obstacles for the group of female faculty members and the mean of scores for the group of male faculty members. The calculated t-value was equal to (1.410) and it is not significant at the level of significance (0.05) and the degree of freedom (59). Table (3) shows that. 


\begin{tabular}{|c|c|c|c|c|}
\hline 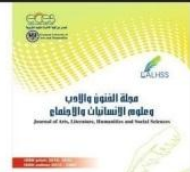 & 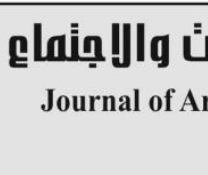 & $\begin{array}{l}\text { liluil| mglo } \\
\text { ts, Literature, Hum } \\
\text { www.jalhs }\end{array}$ & 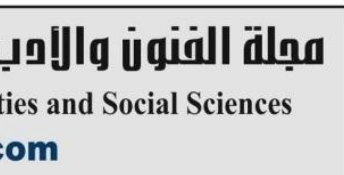 & \\
\hline$=\quad=$ & Volume (74) & December 2021 & العدد (74) ديسمبر 2021 & \\
\hline
\end{tabular}

Table (3)

The differences in total obstacles scores according to gender

\begin{tabular}{|c|c|c|c|c|c|c|}
\hline gender & $\mathrm{N}$ & Mean & Std. Deviation & $\mathrm{t}$ & df & Sig. (2-tailed) \\
\cline { 1 - 5 } Females & 28 & 126.357 & 36.382 & 1.410 & 59 & .164 \\
\hline males & 33 & 114.575 & 28.873 & & & \\
\hline
\end{tabular}

\section{C .Differences according to certificate variable:}

The results of using the t-test for two independent samples showed that there was no statistically significant difference between the mean scores of obstacles for the group of (MA) certificates and the mean of scores for the group of $(\mathrm{PhD})$ certificates. The calculated t-value was equal to (-.279-) and it is not significant at the level of significance (0.05) and the degree of freedom (59). Table (4) shows that.

Table (4)

The differences in total obstacles according to certificate

\begin{tabular}{|c|l|l|c|c|c|c||}
\hline certificate & $\mathrm{N}$ & Mean & Std. Deviation & $\mathrm{t}$ & $\mathrm{df}$ & Sig. (2-tailed) \\
\hline $\mathrm{MA}$ & 42 & 119.190 & 34.302 & $-.279-$ & 59 & .781 \\
\hline $\mathrm{PhD}$ & 19 & 121.736 & 29.994 & & & \\
\hline
\end{tabular}

\section{D .Differences according to academic title variable:}

The results of the comparison using one-way analysis of variance indicated that there are no statistically significant differences in the scores of obstacles according to academic title, as the calculated F-values was equal to $(0.456)$ and it is not significant at the level of significance $(0.05)$ and the degrees of freedom $(2 ; 58)$. As shown in table (5).

Table (5)

The differences in total obstacles according to academic title

\begin{tabular}{|c|c|c|c|c|c|}
\hline \multicolumn{7}{|c|}{ ANOVA } \\
\hline Source & $\begin{array}{c}\text { Sum of } \\
\text { Squares }\end{array}$ & df & $\begin{array}{c}\text { Mean } \\
\text { Square }\end{array}$ & F & Sig. \\
\hline Between Groups & 998.336 & 2 & 499.168 & .456 & .636 \\
\hline Within Groups & 63522.647 & 58 & 1095.218 & & \\
\hline Total & 64520.984 & 60 & & & \\
\hline
\end{tabular}

\section{E .Differences according to Years of experience variable:}

The results of using the t-test for two independent samples showed that there was no statistically significant difference between the mean of obstacles for the group of experience (10) years or less and the mean of scores for the group of experience more than (10) years. The calculated t-value was equal to (- 0.515-) and it is not 


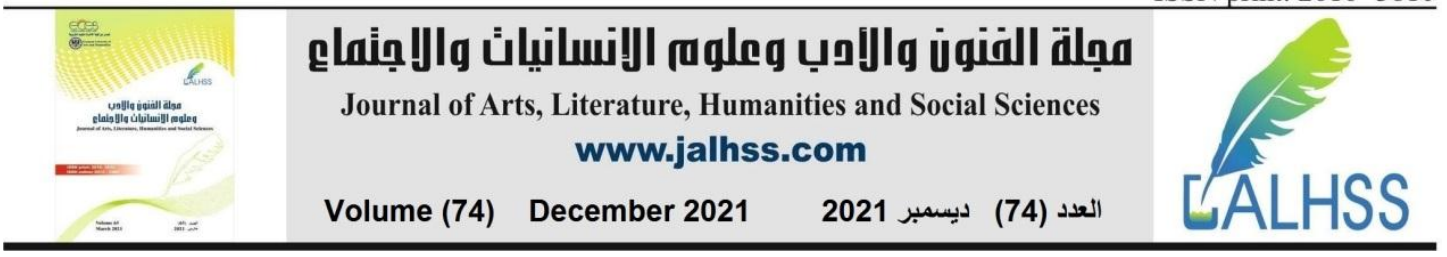

significant at the level of significance (0.05) and the degree of freedom (59). As shown in table (6).

Table (6)

The differences in total obstacles according to years of experience

\begin{tabular}{|c|c|c|c|c|c|c|}
\hline Experience & $\mathrm{N}$ & Mean & $\begin{array}{c}\text { Std. } \\
\text { Deviation }\end{array}$ & $\mathrm{t}$ & $\mathrm{df}$ & Sig. (2-tailed) \\
\hline 10 years or less & 41 & 118.463 & 33.297 & $-.515-$ & 59 & .608 \\
\hline More than 10 years & 20 & 123.100 & 32.349 & & \\
\hline
\end{tabular}

\section{Conclusions:} following:

In the light of the results of the current research, we can conclude the

1. There are many obstacles facing effective teaching in higher education institutions in the Kurdistan Region of Iraq.

2. The obstacles facing effective teaching take a logical arrangement according to the strength of their impact.

3. The inability of higher education institutions to purchase some equipment necessary for effective teaching due to the economic crisis that the region has been experiencing for years, and the resulting lack of financial allocations to universities.

4. There are obstacles facing effective teaching related to the student's personality and thinking pattern resulting from the use of wrong methods in teaching in the previous stages.

5. Demographic factors do not affect the views of faculty members in the universities of the Kurdistan Region regarding the obstacles facing effective teaching.

\section{Recommendations:}

1. The need to financially support universities in the Kurdistan Region of Iraq in order to enable them to provide devices and technologies that would contribute to raising the level of effective teaching in these institutions.

2. Develop the teaching skills of faculty members in higher education institutions to make teaching effective.

3. Training faculty members to use and employ modern technologies in order to raise the level of effective teaching in higher education institutions.

4. Develop students' skills in research and information gathering, and enable them to participate in the lesson to increase effective teaching in educational institutions. 


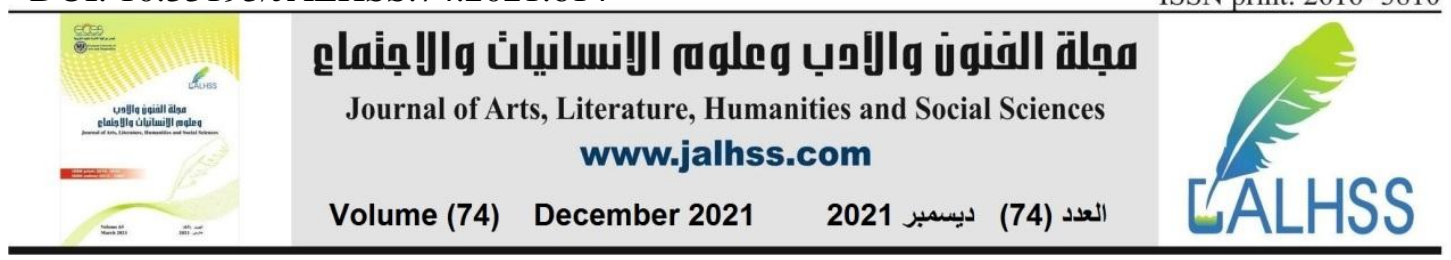

\section{References}

1. Al-Deeb, M. H. (2007). Effective teaching principles and skills . Gaza (Palestine): Dar Afaq for Publishing and Distribution.

2. Al-Maqati, S. b. (2018). Obstacles to the application of modern teaching strategies in teaching religious sciences courses at the secondary level. Journal of Human and Administrative Sciences, Issue (13).

3. Al-Zahrani, B. b. (2010). The role of training courses in developing effective teaching skills for art education teachers from their point of view. A magister message that is not published. College of Education - Umm Al-Qura University.

4. Atkins, M. (1988). Effective Teaching in Higher Education.

5. Attia, M. A. (2008). Modern strategies in effective teaching. Dar Safaa for printing, publishing and distribution.

6. Duvie, M. M. (2012). Innovative Methods and Strategies for Effective Teaching and Learning.

7. Hativa, N. (2000). Teaching for Effective Learning in Higher Education-Springer Netherlands.

8. JHPIEGO., T. d. (2005). Effective Teaching: A Guide for Educating Healthcare Providers.

9. Kyriacou, C. (2009). Effective Teaching in Schools_ Theory and Practice, 3rd Edition.

10. Mocinic, S. N. (2012). Active teaching strategies in higner education. Metodicki obzori 15 , vol. 7.

11. MORENO RUBIO, C. (2009). Effective teachers -Professional and personal skills. ISSN 2171-9098 - ENSAYOS. Revista de la Facultad de Educación de Albacete, No 24,.

12. Mustafa, D. A. (2014). Effective Teaching Strategies. Dar Al-Wafaa to Dunya Printing and Publishing-Egypt First Edition.

13. Mwanamoomba, K. (2014). Effective Teaching Methods in Higher Education. Zambia: Gonzaga University Spokane, Washington.

14. NAHID SHIRANI BIDABADI1*, A. N. (2016). Effective teaching methods in higher education: requirements and barriers. J Adv Med Educ Prof. October 2016; Vol 4 No 4.

15. Ramsden, P. (1992). Learning_to_Teach_in_Higher_Education.

16. Rangaswamy, T. M. (2013). Teaching Methods for Higher Education.

17. Ratib Qassem Ashour, A. R. (2004). The curriculum between theory and practice. Oman: Dar Al-Masira for printing and publishing.

18. Sajjad, D. S. (2010). EFFECTIVE TEACHING METHODS AT HIGHER EDUCATION LEVEL .

19. Sarode, R. D. (2018). Teaching strategies, styles and qualities of a teacher. A review for valuable higher education (IJCESR), VOLUME-5, ISSUE-5, .

20. Sean M. Bulger, D. J. (2000). Stack the Deck in Favor of Your Students by Using the Four Aces of Effective Teaching. Journal of Effective Teaching, Vol. 5, No. 2,.

21. Skelton, A. (2004). Understanding 'teaching excellence' in higher education: a critical evaluation of the National Teaching Fellowships Scheme * University of Sheffield, UK, Studies in Higher Education Vol. 29, No. 4, . 